\title{
Comparative study of maternal and fetal outcome between low and normal amniotic fluid index at term
}

\author{
Gayatri Mathuriya $^{1 *}$, Megha Verma², Sudha Rajpoot ${ }^{3}$
}

\begin{abstract}
${ }^{1}$ Associate Professor, ${ }^{2}$ Third Year PG Student, ${ }^{3}$ First Year PG Student, Department of Obstetrics and Gynaecology, Mahatma Gandhi Memorial Medical College, M.Y. Hospital, Indore, Madhya Pradesh, India
\end{abstract}

Received: 06 December 2016

Accepted: 31 December 2016

\section{* Correspondence:}

Dr. Gayatri Mathuriya,

E-mail: drgayatrimathuriya @gmail.com

Copyright: (c) the author(s), publisher and licensee Medip Academy. This is an open-access article distributed under the terms of the Creative Commons Attribution Non-Commercial License, which permits unrestricted non-commercial use, distribution, and reproduction in any medium, provided the original work is properly cited.

\begin{abstract}
Background: Amniotic fluid index (AFI) is kind of an estimate of the amount of amniotic fluid. It is an index for the fetal well-being. The aim was to study fetal and maternal out come in cases of low AFI and normal AFI.

Methods: This was a case control prospective comparative study performed on 200 randomly selected low risk pregnant patients at term (37-40 weeks of gestation) admitted in Obstetrics and Gynaecology Department. 100 patients with AFI $<5 \mathrm{~cm}$ (cases) and 100 patients with AFI 8-20 cm (control).

Results: Increased number of LSCS in cases that is 35 while only 10 in control and almost equal incidences of MSL and FD in both the groups, while in cases 17 women were planned for elective LSCS for various indications in expectation of better fetal outcome. There was significant low APGAR score in babies of cases, but clinically we refute this. In present study almost double the no. of babies in cases was IUGR or FGR. Significant association between low AFI and congenital anomalies in babies. Most of the anomalies were of urinary tract system.

Conclusions: An AFI $\leq 5 \mathrm{~cm}$ detected at term that was at or after 37 completed weeks of gestation in a low risk pregnancy was an indicator of poor perinatal outcome. Oligohydramnios was being detected more frequently now-adays due to ready availability of ultrasonography these days.
\end{abstract}

Keywords: AFI $<5 \mathrm{~cm}$, Fetal and maternal outcome, Oligohydramnios

\section{INTRODUCTION}

Amniotic fluid index (AFI) is kind of an estimate of the amount of amniotic fluid. It is an index for the fetal wellbeing. ${ }^{1}$ When the volume of amniotic fluid is decreased, it is termed as oligohydramnios. ${ }^{2}$ Oligohydramnios is a common complication of pregnancy and its incidence is $3.9 \%$ of total pregnancy at term. ${ }^{3}$ Low amniotic fluid has been associated with increased risk of maternal morbidity in terms of increased rate of induction of labour and operative interventions, and intrauterine growth retardation, meconium aspiration syndrome, birth asphyxia, low APGAR scores, and congenital anomalies. ${ }^{4,5}$

During labour amniotic fluid provides an adequate cushion for the umbilical cord, this mechanical function of cushion prevent the compression of cord between uterine wall and fetus during fetal movement and uterine contraction, and prevent fetal distress. Amniotic fluid index (AFI) is kind of an estimate of the amount of amniotic fluid. It is an index for the fetal well-being. The amniotic fluid index is measured four quadrants technique by transabdominal ultrasonography as described by Phelan et al in $1997 .{ }^{6}$ The measurement and its comparison to the index is important in helping to determine fetal and maternal health.

- An AFI between 8-20 cm is considered normal

- An AFI 5.1-8 cm is considered as borderline

- An AFI $<5 \mathrm{~cm}$ is considered as low AFI

Aim of the present study was to study fetal and maternal out come in cases of low AFI and normal AFI and to 
determine whether a low AFI during antenatal period at term confers a significant risk of poor perinatal outcome.

\section{METHODS}

The present study entitled Comparative study of maternal and fetal outcome between low and normal amniotic fluid index at term was conducted in the Department of Obstetrics and Gynaecology, M.G.M. Medical College and M. Y. Hospital, Indore, Madhya Pradesh, India during the period from August 2015 to July 2016. Each patient was told about her inclusion and participation in this study and her informed consent was taken. This was a case control prospective comparative study performed on 200 randomly selected low risk pregnant patients at term (37-40 weeks of gestation) admitted in Obstetrics and Gynaecology Department. 100 patients with AFI $\leq 5$ $\mathrm{cm}$ (cases) and 100 patients with AFI 8-20 cm (control) were taken for study after satisfying inclusion and exclusion criteria. Period of gestation was calculated by LMP in patients with regular cycles or by first trimester USG.

\section{Inclusion criteria}

- All singleton pregnancies

- Cephalic presentation

- At term 37-40 weeks (gestational age will be calculated by LMP or by first trimester USG)

- Intact membranes.

- Women and/or his/her legally acceptable representative willing to provide their voluntary written informed consent for participation in the study.

\section{Exclusion criteria}

- Gestational Age <37 Weeks and >40 weeks

- PROM.

- Uterine Anomaly.

- Malpresentation

- Multiple gestation

- High Risk pregnancy

a. Hypertensive disorders of pregnancy

b. Diabetes

c. Chronic renal disease / cardiac disease and other medical ailment

d. Connective Tissue disorder

e. Vaginal Bleeding (Abruption)

- $\mathrm{BOH}$

- Previous lower segment cesarean section/ myomectomy/ hysterotomy.

- Women and/or his/her legally acceptable representative not willing to provide their voluntary written informed consent for participation in the study.

Data was transcribed from the proforma to Microsoft excel and then transferred to statistical package IBM
SPSS Version 20.0.0 for analysis. Comparison of means between the groups was done using Unpaired ' $t$ ' test. Non-parametric data was analysed using Pearson's chisquare / Mann Whitney U test. A P value of $<0.05$ was taken as statistically significant. The final data was presented in the form of tables and graphs.

\section{RESULTS}

The grouping was based on the AFI. AFI $\leq 5 \mathrm{~cm}$ was taken as Cases and AFI between $8-20 \mathrm{~cm}$ was taken as Controls. $88 \%$ women were unbooked cases, while $68 \%$ of women of the controls were unbooked. The mean age of women in cases was $24.40 \pm 3.81$ years, while it was $23.83 \pm 3.77$ years in controls. Majority of the women were in the age group 21-25 years in both the groups. Maximum number of women (37\% of Cases and $48 \%$ of Controls) were Gravida 1. Pearson Chi-square value was 11.655. The $\mathrm{P}$ value was 0.001 (significant) (Table 1).

Table 1: Distribution according to booked and emergency cases, age, gravida and parity.

\begin{tabular}{|l|l|l|l|l|}
\hline & $\begin{array}{l}\text { Cases } \\
\text { No. of } \\
\text { patients }\end{array}$ & $\%$ & $\begin{array}{l}\text { No. of } \\
\text { patients }\end{array}$ & $\%$ \\
\hline Booked & 12 & 12 & 32 & 32 \\
\hline $\begin{array}{l}\text { Unbooked } \\
\text { /Emergency }\end{array}$ & 88 & 88 & 68 & 68 \\
\hline $\begin{array}{l}\text { 21-25 years } \\
\text { age }\end{array}$ & 52 & 52 & 51 & 51 \\
\hline Gravida 1 & 37 & $37 \%$ & 48 & $48 \%$ \\
\hline Gravida 2 & 26 & $26 \%$ & 22 & $22 \%$ \\
\hline Gravida 3 & 20 & $20 \%$ & 20 & $20 \%$ \\
\hline$\geq$ Gravida 4 & 17 & $17 \%$ & 10 & $10 \%$ \\
\hline Para 0 & 44 & 44 & 52 & 52 \\
\hline Para 1 & 36 & 36 & 31 & 31 \\
\hline Para 2 & 16 & 16 & 15 & 15 \\
\hline Para 3 & 03 & 03 & 2 & 2 \\
\hline Para 4 & 01 & 01 & 0 & 0 \\
\hline
\end{tabular}

Table 2: Distribution according to mode of delivery.

\begin{tabular}{|l|l|l|l|l|}
\hline Mode of & Cases & \multicolumn{3}{c|}{ Control } \\
\hline Delivery & No. & $\%$ & No. & $\%$ \\
\hline LSCS & 35 & 35 & 10 & 10 \\
\hline $\begin{array}{l}\text { Vaginal } \\
\text { Delivery }\end{array}$ & 65 & 65 & 90 & 90 \\
\hline Total & 100 & $100 \%$ & 100 & $100 \%$ \\
\hline
\end{tabular}

In cases, more number of women (35\%) in comparison to $10 \%$ of controls had undergone LSCS, while in Controls $90 \%$ of the women were delivered normally. Pearson Chi-square value was 17.921 . The $\mathrm{P}$ value was 0.000 (significant) (Table 2). Elective cesarean section 17 $(48.5 \%)$ was the most common indication for LSCS in cases, while other indications were foetal distress, MSL, non-progress of labour and failed induction were the next most common indications in both the groups (Table 3). 
Table 3: Indication for LSCS.

\begin{tabular}{|c|c|c|c|c|}
\hline \multirow{2}{*}{$\begin{array}{l}\text { Indication for } \\
\text { LSCS }\end{array}$} & \multicolumn{2}{|c|}{ Cases } & \multicolumn{2}{|c|}{ Control } \\
\hline & No. & $\%$ & No. & $\%$ \\
\hline Total LSCS & 35 & 35 & 10 & 10 \\
\hline Foetal distress & 5 & 14.2 & 4 & 40 \\
\hline MSL & 3 & 8.5 & 4 & 40 \\
\hline Elective section & 17 & 48.5 & 0 & 0 \\
\hline $\begin{array}{l}\text { a. Loop of cord } \\
\text { around neck }\end{array}$ & 1 & 2.8 & 0 & 0 \\
\hline $\begin{array}{l}\text { b. Uteroplacental } \\
\text { insufficiency }\end{array}$ & 7 & 2 & 0 & 0 \\
\hline $\begin{array}{l}\text { c. Absent diastolic } \\
\text { flow }\end{array}$ & 4 & 11.4 & 0 & 0 \\
\hline $\begin{array}{ll}\text { d. } & \text { Reversed } \\
& \text { diastolic flow }\end{array}$ & 5 & 14.2 & 0 & 0 \\
\hline $\begin{array}{l}\text { Non progressive } \\
\text { Labour }\end{array}$ & 3 & 8.5 & 1 & 10 \\
\hline Failed induction & 6 & 17 & 0 & 0 \\
\hline Obstructed labour & 0 & 0 & 1 & 10 \\
\hline
\end{tabular}

Table 4: Distribution of APGAR score, nursery admissions and IUGR.

\begin{tabular}{|c|c|c|c|}
\hline \multicolumn{2}{|c|}{ Observations } & Cases & Control \\
\hline \multirow{2}{*}{$\begin{array}{l}\text { APGAR } \\
\text { score at } 5 \\
\text { min. }\end{array}$} & $8-10$ & 68 & 80 \\
\hline & $\leq 7$ & 32 & 20 \\
\hline \multicolumn{2}{|c|}{ Nursery admission } & 28 & 17 \\
\hline \multirow[t]{2}{*}{ IUGR } & Alive & 17 & 09 \\
\hline & IUD & 01 & 00 \\
\hline
\end{tabular}

Table 5: Congenital anomalies.

\begin{tabular}{|l|l|l|l|l|}
\hline Name of Congenital & Cases & \multicolumn{2}{c|}{ Control } \\
\hline anomaly & No. & $\%$ & No. & $\%$ \\
\hline Urinary tract system & 4 & 4 & 0 & 0 \\
\hline Hydronephrosis /hydroureter & 2 & 2 & 0 & 0 \\
\hline Renal agenesis & 1 & 1 & 0 & 0 \\
\hline Renal ectasia & 0 & 0 & 0 & 0 \\
\hline Polycystic kidney disease & 1 & 1 & 0 & 0 \\
\hline Posterior urethral valve & 0 & 0 & 0 & 0 \\
\hline Potter syndrome & 0 & 0 & 0 & 0 \\
\hline CTEV & 1 & 1 & 0 & 0 \\
\hline Amniotic band syndrome & 0 & 0 & 0 & 0 \\
\hline Pulmonary hypoplasia & 0 & 0 & 0 & 0 \\
\hline Hydrocephalus & 1 & 1 & 1 & 1 \\
\hline Gastrointestinal system & 0 & 0 & 0 & 0 \\
\hline Cardiac anomaly & 0 & 0 & 0 & 0 \\
\hline
\end{tabular}

Large numbers of babies (32) in cases were having low APGAR score at $5 \mathrm{~min}$ in comparison to 20 of the controls. The mean weight of babies born in cases $(2.45 \pm 0.42 \mathrm{~kg})$ was nearly comparable to the weight of babies born in controls $(2.55 \pm 0.50 \mathrm{~kg})$. Unpaired t-test was applied. The $\mathrm{P}$ value was 0.109 (insignificant). IUGR was more in cases (17) in comparison to the controls (9), but this difference was statistically not significant. Mann
Whitney U value for AFI and APGAR score at 5 min was 4350.000 and $P$ value was 0.000 (significant) (Table 4). Congenital anomalies were mostly seen in cases, while only 1 case of hydrocephalus was seen in the controls. Statistically significant association was seen between congenital anomalies and groups (Pearson Chi-square value was 3.701 , the $P$ value was 0.054 , the value was borderline and can be considered as significant in the study (Table 5).

\section{DISCUSSION}

There were evidences that show significant increase in perinatal morbidity and mortality in patients with oligohydramnios at term.

Most of the cases and controls were belonging to age group 21-25 years i.e. cases 52\% and controls 51\%. The mean age of cases was $24.4 \pm 3.81$ years in cases and $23.83 \pm 3.77$ years for controls. Present study results corroborate with the results of the studies done by Zhang et al found mean age of $28.4 \pm 3.4$ years, Jagatia et al found mean age of 23.9 years, Hindumati et al found mean age of 22.5 years and Sangeeta et al found mean age of 23.1 years in cases and 22.6 years in controls. ${ }^{7-10}$

In present study it was observed that in cases only $12 \%$ were booked and $88 \%$ were unbooked. In control $32 \%$ were booked and $68 \%$ were unbooked. More number of unbooked cases was significantly associated with low AFI.

It was found in this study that there was no statistical difference between gravidity and parity in the two study groups. Most of the women $37 \%$ of cases and $48 \%$ of controls were primigravida. $44 \%$ of the cases and $52 \%$ of the controls were para 1 . Study done by Hindumati et al found a 59\% of incidence of oligohydramnios in primipara. Our study results are also comparable to the studies done by Asgharnia et al, Gumus et al and Voxman et al. ${ }^{9,11-13}$

In present study, $55 \%$ of the women of cases and $67 \%$ of controls were from urban area. $71 \%$ of the cases and $83 \%$ of the controls were in the upper lower class (Kuppuswamy Classification).

Twenty nine women were induced and 6 were failed induction in the cases, while only 1 woman was induced in the controls. The decision for induction or allowing for spontaneous labour was taken depending upon the stage of labour, favourability of the cervix and AFI. Study done by Sangeeta et al reported $56 \%$ induction in cases and $36 \%$ induction in controls; they have shown a higher incidence of induction in comparison to our study. ${ }^{10}$

$65 \%$ of the cases and only $10 \%$ of controls underwent LSCS in this study, while $90 \%$ of the controls were delivered vaginally. Higher incidence of LSCS was seen in cases in comparison to the controls. In a study done by 
Sangeeta et al $22 \%$ of the cases and $4 \%$ of the controls underwent LSCS. ${ }^{10}$ In Hindumati et al study, $47 \%$ of the women underwent LSCS and Umber et al reported $32 \%$ incidence. Studies done by Casey et al, Golan et al and Rainford et al reported $32 \%, 35.2 \%$ and $33.3 \%$ of LSCS respectively in oligohydramnios groups..$^{9,14-17}$

Elective cesarean section $(48.5 \%)$ was the most common indication of LSCS in our study, while it was $2.8 \%$ due to color doppler changes and loop of cord around neck. The decision for elective cesarean section was taken for improving the fetal outcome. Other indications included fetal distress (14.2\%), MSL (8.5\%), non-progress of labour $(8.5 \%)$ and failed induction $(17 \%)$. However, in controls $40 \%$ of women had undergone LSCS for fetal distress, $40 \%$ due to MSL, $10 \%$ for non-progress of labour and $10 \%$ for obstructed labour. MSL and fetal distress incidence was nearly equal in both the groups. Studies done by Hindumati et al, Casey et al found fetal distress in $17 \%$ and $48 \%$ respectively as the most common indication for LSCS, while Umber et al found thick MSL in $6 \%$ to be the indication for LSCS. ${ }^{9,14-15}$

Congenital anomalies were mostly seen in cases, while only 1 case of hydrocephalus was seen in controls. Statistically significant association was seen between low AFI and babies having congenital anomalies (Pearson chi-square value $=3.701, \mathrm{P}$ value $=0.054$, though borderline, can be considered as significant). In $6 \%$ of the babies in cases, congenital anomalies were related to urinary tract system. Incidence of congenital anomalies reported by Shetty et al was $8 \%, 5.8 \%$ by Guin et al, $8.5 \%$ by Golan et al and $11 \%$ by Shenker et al. ${ }^{16,18-20}$

APGAR score of babies at 1 min and 5 min was 8-10 for $61 \%$ and $68 \%$ cases and $\leq 7$ for $39 \%$ and $32 \%$ of cases respectively while $77 \%$ and $80 \%$ in $8-10$ and $23 \%$ and $20 \%$ in $\leq 7$ for control. It is comparable to the study of Chate $\mathrm{P}$ score $<7$ in study group was $30 \%$ at $1 \mathrm{~min}$. and $16 \%$ at 5 min. ${ }^{21}$ In this study, $\mathrm{P}$ value at $1 \mathrm{~min}$. was 0.016 and at $5 \mathrm{~min} P$ value was 0.000 . Statistically it was significant but clinically we refute this. The variation was very likely in different sample sizes. In a similar study by Syria et al APGAR score $<7$ was found to be in $38.8 \%$, less than 3 in $6 \%$ in study by Casey et al and. ${ }^{15,22}$ There was no significant difference for APGAR score in study and control group in the study by Locatelli A et al. ${ }^{23}$

In the present study IUGR babies were $18 \%$ in cases and $9 \%$ in control. $\mathrm{P}$ value was 0.109 . The mean value of weight of baby born to case group was $2.449 \pm 0.4190$ and in control group was $2.554 \pm 0.5036$ years. So statistically it showed no significant association between low AFI and IUGR/FGR babies, which was comparable to study of Raju Sriya et al, which has $16.6 \%$ IUGR in oligohydramnios. ${ }^{24}$

In this study most of the babies were alive and healthy i.e. $71 \%$ in cases and $82 \%$ in controls while $28 \%$ of babies among cases and $17 \%$ of babies among controls went to NICU. The P value was 0.176 . A study by Sriya showed a higher incidence of $88.88 \%$ admission to NICU while $4 \%$ in study of Sangeetha et al. ${ }^{10,24}$

$1 \%$ of babies were stillbirth in each category. Out of the babies going to nursery or NICU, $17.8 \%$ i.e. 5 out of 28 babies died and $82 \%$ were alive and healthy in cases category. Long term management of alive babies with congenital anomalies were not studied in the study. None of the babies died in Control category.

\section{CONCLUSION}

Oligohydramnios is being detected more frequently nowa-days due to ready availability of ultrasonography these days. An AFI $\leq 5 \mathrm{~cm}$ detected at term that is at or after 37 completed weeks of gestation in a low risk pregnancy is an indicator of poor perinatal outcome.

Intensive fetal monitoring is essential for patients in labour. Due to increased risk of neonatal complications in oligohydramnios the rate of LSCS is also increasing but decision between vaginal delivery and ceasarean section should be well balanced so that unnecessary maternal morbidity prevented. Timely intervention is also required to reduce perinatal morbidity and mortality

\section{ACKNOWLEDGEMENTS}

Authors would like to thank Dr. Nilesh Dalal, Professor and Head, Department of Obstetrics and Gynaecology, M.G.M. Medical College and M.Y. Hospital, Indore for allowing us to publish this paper. We are thankful to all our parents for their kind cooperation.

\section{Funding: No funding sources \\ Conflict of interest: None declared}

Ethical approval: The study was approved by the Institutional Ethics Committee of M.G.M. Medical College and M.Y. Hospital, Indore.

\section{REFERENCES}

1. Winter TC, Sanders, Roger C. Clinical Sonography: A Practical Guide. Hagerstown, MD: Lippincott Williams and Wilkins. ISBN 0-7817-4869-0. 2006:502.

2. Phillipson EH, Sokot RJ, Williams TW. Oligohydramnios Clinical associations and predictive value for intrauterine growth retardation. Am J Obsctet Gynecol. 1983;146(3):271-6.

3. Rainford M, Adair R, Scialli AR, Ghidini A, Spong CY. Amniotic fluid index in the uncomplicated term pregnancy. Prediction of outcome. J Reprod Med. 2001;46(6):589-92.

4. Sultana S, Khan AMN, Akhtar KKA, Aslam M. Low amniotic fluid index in high-risk pregnancy and poor APGAR score at birth. J Coll Physicians Surg Pak. 2008;18(10):630-4. 
5. Phelan JP, Smith CV, Broussard P, Small M. Amniotic fluid volume assessment using the fourquadrant technique in the pregnancy at 36-42 weeks gestation. J Reprod Med. 1987;32(7):540-2.

6. Manning FA, Platt LD, Sipos J. Antepartum fetal evaluation. Development of a fetal biophysical profile. Am J Obstet Gynecol. 1980;136:787-95.

7. Zhang J, Troendle J, Meikle S, Klebanoff MA, Rayburn WF. Isolated oligohydramnios is not associated with adverse perinatal outcome. Int J Gyneccol Obstet. 2004;111(3):220-5.

8. Jagatia K, Singh N, Patel S. Maternal and Fetal Outcome in Oligohydramnios, Int J Med Sci Public Health, 2013;2(3):724-7.

9. Hindumathi, M. Karthiki, J. Ramamani, Sivajyothi. A prospective Study of Maternal and Fetal Outcome in Oligohydramnios in Rural Area. IJRAMR. 2015;2(11):985-8.

10. Sangeetha K, Rao J, Ashwini AP, Kumar A. Pregnancy Outcome in amniotic fluid index less than 5 in term low risk pregnancy. Int J Sci Stud. 2015;3(3):69-73.

11. Gumus II, Koktener A, Turhan NO. Perinatal outcome of pregnancies with borderline amniotic fluid index. Arch Gynecol Obstet. 2007;276:17-9.

12. Voxman EG, Tran S, Wing DA. Low amniotic fluid index as a predictor of adverse perinatal outcome. J Perinatol. 2002;22(4):282-5.

13. Asgharnia M, Faraji R, Salamat F, Ashrafkhani B, Heirati SFD, Naimian S. Perinatal outcomes of pregnancies with borderline versus normal amniotic fluid index. Iran J Reprod Med. 2013;11(9):705-10.

14. Umber A. perinatal outcome in pregnancies complicated by isolated oligohydramnios at term. Annals. 2009;15(1):35-7.

15. Casey BM, Mcintire DD, Bloom SL, Lucas MJ, Santos R, Twickler DM. Pregnancy outcome after diagnosis of oligohydramnios at or beyond 34 weeks gestation. Am J Obstet Gynecol. 2000;182(4):90912 .
16. Golan A, Lin G, Evron S, Arieli S. Oligohydramnios: maternal complications and fetal outcome in 145 cases. Gynecol Obstet Invest. 1994;37(2):91-5.

17. Rainford M, Adiar R, Scialli AR, Ghidini A. Spong CY. Amniotic fluid index in uncomplicated term pregnancy. Prediction of outcome. J. ReprodMedicine. 2001;46(6):589-92.

18. Shetty A, Shetty S, Rai SB. A study of congenital anomalies and perinatal outcome in oligohydramnios. Int $\mathbf{J}$ Med Sci Public Health. 2013;2(4):1081-3.

19. Guin G, Shweth P, Arvind L, Shashi K. A prospective clinical study of feto-maternal outcome in pregnancies with abnormal liquor volume. J Obstet Gynaecol India. 2011;61(6):652-5.

20. Shenker L, Reed KL, Anderson CE, Borjon NA. Significance of oligohydramnios complicating pregnancy. Am J Obstet Gynecol. 1991;164(6 Pt 1):1597-9.

21. Chate P, Khatri M, Hariharan C. Pregnancy outcome after diagnosis of oligohydramnios at term. Int $\mathbf{J}$ Reprod Contracept Obstet Gynecol. 2013;2:23-6.

22. Sriya R, Singhai S. Perinatal outcome in patients with amniotic fluid index $<5 \mathrm{~cm}$. J Obstet Gynaecol India. 2001;51:98-100.

23. Ahmad A. Role of intravenous amino acid infusion in cases of oligohydramnios and its effect. JKPractitioner. 2006; 13(3):140-1.

24. Sriya R, Singhai S. Perinatal outcome in patients with amniotic fluid index $<5 \mathrm{~cm}$. J Obstet Gynecol India. 2001;51:98-100.

Cite this article as: Mathuriya G, Verma M, Rajpoot $\mathrm{S}$. Comparative study of maternal and fetal outcome between low and normal amniotic fluid index at term. Int J Reprod Contracept Obstet Gynecol. 2017;6:640-4. 